\title{
PREFACE TO THE UPDATED EDITION
}

I wrote the bulk of When the Money Runs Out in 2012. Four years after the collapse of Lehman Brothers, the event now regarded by many as the 'trigger' for the global financial crisis, I sensed that the policy debate was too narrowly focused on what was likely to prove the wrong issue. Specifically, while I had read and heard a great deal about the relative merits of stimulus versus austerity - ultimately a debate about the best way of delivering a return to economic 'normality' - it struck me that there was too little discussion about the possibility that 'normality' as previously understood was no longer within reach. I feared that we were on the verge of a permanent slowdown in economic growth, one that threatened severe political upheaval.

Admittedly, I had my own biases. Having spent the early 1990s analysing the Japanese economy, I was perhaps more worried than most that economies could slow structurally. Many in the West had looked at Japan with an air of amused detachment, taking the view that its 'lost decades' were something that would never happen elsewhere. I thought this attitude was far too complacent. After all, the West had 


\section{Preface to the updated edition}

just been through a financial upheaval in many ways more violent than Japan's own experience: more countries were involved and the initial losses in economic activity were far bigger than anything that Japan had suffered. If Japan's economy could enter a period of persistently much weaker growth, why would the West be immune?

Six years later, we now know that the West has, indeed, endured a 'lost decade' which, in the majority of cases, has been even more disappointing than Japan's version. And it appears that the problem is structural rather than cyclical: unemployment rates have dropped rapidly - a good thing - but the pace of economic recovery has been unusually weak. Productivity growth has been poor - despite huge progress in IT, AI and robotics - and unfavourable demographic trends have begun to kick in, just as they had done in Japan in the early 1990s. Debt levels are high, inflation is, for the most part, too low, borrowing costs have fallen to Japanese levels, and fiscal positions are far weaker than had been anticipated. Like Japan, the combination of weak fiscal positions and very low interest rates means that policymakers are ill-prepared to cope in the event of another recession: there just isn't very much conventional 'ammunition' left.

Persistently weak growth has led to much greater concerns about inequality. This should come as no great surprise. Societies in which incomes are rising rapidly can more easily tolerate inequality because even those who are 'left behind' are still likely to become richer over time. Societies in which incomes are rising only slowly face a much bigger problem: those who are left behind may well end up poorer over time. That problem is only amplified if the primary effect of monetary stimulus is to raise the value of financial assets while doing little to stimulate economic growth: the already-wealthy end up wealthier still.

The response to these persistent disappointments has itself been disappointing. Post-crisis, the policymaking conventional wisdom has not really shifted very far. Admittedly, regulators demanded that banks should hold more capital and liquidity to prevent another 


\section{Preface to the updated edition}

Lehman-style meltdown, but, beyond that, much of the old framework remains in place: inflation targeting is still the dominant monetary framework; capital moves relatively freely across borders; and asset bubbles are not taken terribly seriously. There is a grudging acceptance that something has gone badly wrong with productivity growth, but few are prepared to contemplate the idea that persistent monetary stimulus - which appears indiscriminately to have inflated the value of financial assets - may have played a role by distorting the signals within capital markets that, in other circumstances, would have led to better productivity outcomes.

The political consequences have been disturbing. Increasingly, the debate is not so much about 'win-win' reforms, but rather about 'them and us'. We are witnessing a return of the protectionist, isolationist and anti-immigration attitudes that had lain dormant during the golden era of Western affluence. The slowdown in Western economic growth has multiple causes (and, in part, reflects our failure to recognise the temporary factors that had boosted economic growth so much during the golden era itself), yet, as history has demonstrated on so many occasions, it is often easier to lay the blame squarely on the foreigner, the immigrant, the minority or the new rising power. Scapegoating, however, will likely end in tears.

For this updated edition of When the Money Runs Out, I have revisited all relevant data and, where appropriate, have revised the narrative to take into account subsequent economic and political developments. However, it should not be seen as a book about, for example, Brexit or Trump. Both can be regarded as plausible political responses to the themes described within these pages, but when I first put pen to paper (or keystrokes to screen), they were very much stories of the future: I did not feel that I should use hindsight to pretend I was more prescient than I could reasonably have claimed to have been. 
